ELORE (ISSN 1456-3010), vol. 18 - 2/2011.

Julkaisija: Suomen Kansantietouden Tutkijain Seura ry.

[http://www.elore.fi/arkisto/2_11/vakimo.pdf]

\title{
KOLUMNI
}

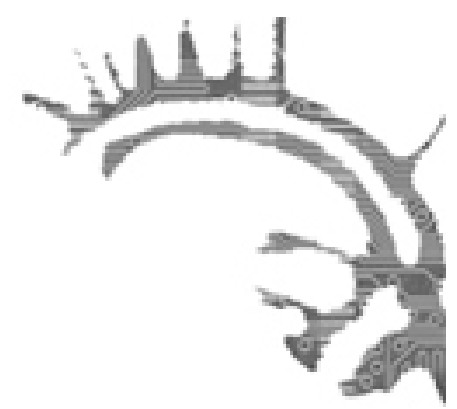

\section{Pahoin- ja hyvinvointia Yliopistolla}

\author{
Sinikka Vakimo
}

Ei ole lääkäreilläkään helppoa. Tästä kirjoitti viime sunnuntain Hesarissa (27.11. 2011) kiinnostavan vieraskynä-kirjoituksen lääketieteen tohtori Pirjo Lindfors. Hän eritteli kirjoituksessaan läkäreiden, tarkemmin sanoen anestesialääkäreiden työhyvinvointia otsikolla "Lääkäreiden pahoinvoinnilla on laajat seuraukset". Kirjoitus perustuu Lindforsin vuonna 2010 julkaistuun väitöskirjaan. Kuten kirjoituksen otsikkokin jo kertoo, Lindforsin tarkastelusta muodostuu paremminkin lääkäreiden pahoinvoinnin kuin hyvinvoinnin erittely. Siinä esitetään syvä huolestuminen tilanteesta ja arvellaan sen osaltaan mahdollistaneen ns. valelääkäri-ilmiön. Vaikka meillä ei vielä keskustella valeperinteentutkijoista, kirjoitus herätti ajatuksia. Koin tekstiä lukiessani monissa kohdin kuvattavan varsin tuttuja asioita omassa työkulttuurissani. Se pisti myös miettimään, kuka esittäisi syvän huolestuneisuutensa meidän, humanistien työpahoinvoinnista ja sen seurauksista?

Aloin pohtia mielessäni, miksi jotkut lääkäreille työpahoinvointia aiheuttaneet seikat tuntuivat minusta niin tutuilta vaikka oma työkokemukseni sijoittuu ihan toisenlaiseen akateemiseen sfääriin humanistisen alan opettajana ja tutkijana yliopistossa. Ilmeisesti ainakaan kaikki Lindforsin tutkimuksessaan esiin nostamat ongelmat eivät perustu pelkästään lääkäreille ominaiseen työkulttuuriin ja lääkärikoulutukseen, vaan paikantuvat laajemminkin yliopiston maailmaan.

Ihmettelen tätä seikkaa kirjoituksessani vähän tarkemmin. Suhteutan tarkasteluni tyystin omaan subjektiiviseen, yli kaksikymmenvuotiseen työkokemukseen verraten pienessä yliopistossa, Joensuussa. Lisäksi käytän taustatukenani eri akateemisia aloja - myös luonnontieteellisiä - edustavan kymmenisen yliopisto-opettajan kokemuksia. Tämän porukan kanssa olemme toistuvasti pähkäilleet, ruikuttaneet ja kironneet yliopistotyötä, sen puutteita ja epäinhimillisyyttä. Olemme myös yrittäneet löytää hyviä asioita työssämme ja keksineet kaikenmoisia parantamismahdollisuuksia työmme arjessa ollessamme ASLAK-kuntoutuksessa jo yli vuoden ajan.

Lindforsin mukaan lääkäreiden huonovointisuutta lisäsi lääkäreiden ammattikulttuuri ja ammatillisen itsemäärämisoikeuden vähäisyys, organisaation oikeudenmukaisuuden 


\section{Sinikka Vakimo: Pahoin- ja hyvinvointia yliopistolla}

puute ja työpaikan ihmissuhdeongelmat. Lääkäreiden ammattikulttuurista on tullut epäinhimillistä: uuden teknologian lisääminen, kiihtyvä ja tiukentuva tulosvastuuajattelu sekä jatkuvat organisaatiomuutokset ovat radikaalilla tavalla muokanneet potilaan ja lääkärin suhdetta sellaiseksi, ettei kukaan ole tilanteeseen tyytyväinen. Paitsi kenties lääkärintyöstä kertyvien kulujen laskija, jos hänkään. - Ja näinhän se on meilläkin yliopistoissa, samaa tulostavoitteiden, organisaatiomuutosten ja jatkuvasti uusien opeteltavien tietokoneohjelmien huttua on meillekin syötetty jo pitkään.

Lisäksi lääkäreitäkin jurppii työnteon ja tutkimuksen teon byrokratian kasvaminen, tutkimusrahoituksen kilpailun kiihtyminen ja kansainvälisyyden kohtuuton korostaminen osana tutkimuksen tekoa. Humanistiopettajana lisään tähän työpahoinvoinnin aiheuttajien listaan vielä tutkimuksenteon riittämättömän resurssoinnin. Työaikaa, avustavaa henkilökuntaa ja kielentarkastusvaroja on liian vähän, jolloin opettavalla ja hallintoa pyörittävällä yliopiston työntekijällä jää tutkimuksen teko väkisinkin pätkittäiseksi huiskimiseksi ja loma-aikoihin. Kyllä siinä tuppaa innostus ja innovointivimma hiljalleen laantumaan ja pahimmassa tapauksessa tutkimuksenteko saattaa jäädä kokonaan. Nämä seikat eivät tietystikään ole meille kenellekään yliopistossa arkeamme viettävälle uusia havaintoja. Monista selvityksistähän käy ilmi, että yliopistolaiset voivat työssään aika kehnosti ja työuupumus häämöttää monen lähihorisontissa.

Lääkäreiden kokema itsemääräämisoikeuden kaventuminen ja organisaation epäoikeudenmukaistuminen ovat tuttuja meillekin. Uusi yliopistorakenne on entisestään vienyt päätöksentekoa etäämmälle ja tehtäviä ja toiminnan suuntia sanellaan meille yhä enemmän jostain ylhälltä eli yliopiston hallinnosta ja Opetus- ja kulttuuriministeriöstä. Lääkäreiden työtä haittaavat työpaikan ihmissuhdeongelmat sen sijaan ovat ainakin omassa lähityöyhteisössäni lähes tuntematon ilmiö. Ja tästä olen ollut ylpeä myös monitieteisessä ASLAK-porukassa, jossa onkin ilmiselvästi oltu kateellisia meikäläisen röyhistelylle. Kannustavat ja omaa työtä tukevat työkaverit ja välitön tunnelma työpaikalla ovat aika olennaisia asioita - porukan tuella jaksaa pitkälle.

Ammattikulttuurin tarkastelun lisäksi Lindfors nostaa kiinnostavasti esiin ongelmat, jotka koskevat lääkärinkoulutusta ja ammatinharjoittamista säätelevää arvomaailmaa ja etiikkaa sekä näiden välisiä ristiriitoja. Hän mainitsee muun muassa, että lääketieteelliset tiedekunnat kyllä opettavat tiedettä, mutta laiminlyövät lääkärin taitojen ja moraalin opettamisen. Koulutuksessa ei ohjata riittävästi työn merkityksellisyyden ja potilaan kohtaamisen kysymyksiin.

Humanistin työpahoinvointia lähemmäksi siirrytään, kun todetaan, että lääkärit joutuvat nykytilanteessa toimimaan vastoin eettisiä periaatteitaan. Tulosvastuuajattelu ei anna mahdollisuuksia antaa korkeatasoista hoitoa ja opetusta. Tämä kaventaa lääkärin toimijuutta ja itsemääräämisoikeutta työssään. Jatkuva toiminta omaa arvomaailmaa vastaan aiheuttaa eettistä väkivaltaa ja sen myötä "ristiriitaisia tuntemuksia ja lopulta, pettymyksiä, itsensä epäilyä, pahoinvointia, vetäytymistä omista ihanteista ja empatian puutetta”, kuvaa Lindfors. - Tässä ollaan nähdäkseni asian ytimessä: jatkuva omia arvoja vastaan toimiminen ja eettisistä periaatteista lipsuminen syö miestä, kuten mies voisi sanoa.

Ammatissa ja työssä toteutettava arvomaailma ja etiikka ovat jotakin, johon kasvetaan ja jotka omaksutaan ajan kuluessa opintojen ja työteon aikana. Yliopisto ja 
akateeminen maailma ovat nälttä osin muuttuneet radikaalisti omista akateemisen urani alkuvaiheista. Toki nykyisin kaikki yliopistot kirjaavat toimintaansa ohjaaviksi arvoikseen mitä kannatettavimpia arvoperiaatteita. Näitä vain on arkityössä vaikeaa seurata, kun kiire pukkaa päälle ja mitattavaa tulosta pitäisi tulla. Opettaja ja tutkija joutuukin jatkuvasti tinkimään niistä hyvän työnteon eettisistä periaatteista, jotka itse on sisäistänyt ja joita pitää tärkeänä. Ja tätä jatkuvaa ristiriitaa ei ratkaista "tehostamalla" toimintaa opetusteknologiaa kehittämällä ja lisäsoveltamisella, ei kiihtyvällä kokousja palaverirumballa, ei arviointien, seurannan ja kontrolloinnin vyöryllä arjessa. Ei, jotain muuta on tehtävä.

Kuka kantaisi huolta ja myös vastuuta meidän pahoinvoinnistamme ja sen seurauksista - innottomasta, rutiininomaisesta opetuksesta ja tutkimuksesta ja epäempaattisesta ohjauksesta? Eikö yliopiston työnantajana ja työn puitteiden tarjoana pitäisi antaa myös työntekijöilleen mahdollisuus sellaiseen eettiseen toimijuuteen, jonka he katsovat omalta kohdaltaan tärkeäksi? Humanistin työssä viihtymisen kannalta tämä on ymmärtääkseni aivan keskeisimpiä asioita. Mahdollisuus eettiseen toimijuuteen takaa työn mielekkyyden, itsemääräämisoikeuden ja kehittymisen kokemusten säilymisen. Palkka tuskin on humanisteille koskaan ollut samalla tavalla merkittävä työmotivaation lähde kuin lääkäreillä. Tietysti myös ministeriöllä ja akatemialla on roolinsa yliopistolaisten työpahoinvoinnissa: ne asettavat yliopistoille ja kaikelle akateemiselle toiminnalle ne kehykset ja vaatimukset, joihin meidän kenttätason opettajien ja tutkijoiden on vain sopeuduttava oman työhyvinvointimme uhallakin.

Kirjoituksensa lopussa lääketieteen tohtori Pirjo Lindfors esittää kulttuurintutkijoita kiinnostavan ratkaisuehdotuksen lääkäreiden työpahoinvointiin. Hänen mielestään lääkäreiden olisi luovuttava kaikkivoipaisuuden uskostaan ja toimittava yhteistyössä sekä filosofien että kulttuurintutkijoiden kanssa ja otettava vielä mukaan hoitajat ja potilaatkin, jotta organisaatiokulttuuri tervehtyisi. - Mikäs sen mairittelevampaa kulttuurintutkijalle, kun joku meitä arvostaa ja pyytää apuun. Paljon meillä varmasti olisikin annettavaa niin lääkäreiden kuin muidenkin työorganisaatioiden tutkimuksessa ja laajemminkin terveyden kulttuuristen aspektien soveltavassa tutkimuksessa. Ja paljon myös itsellä opittavaa. Mutta lääkäreiden auttaminen olisi kannatettavaa myös ihan itsekkäistä syistä: heihinhän humanistitkin viimekädessä turvautuvat, kun paukut on työssä kuluneet loppuun.

FT Sinikka Vakimo on perinteentutkimuksen yliopistonlehtori, joka hoitaa sukupuolentutkimuksen professuuria Itä-Suomen yliopistossa. 